Tanjungpura Law Journal, Vol. 4, Issue 2, July 2020: 133 - 160

ISSN Print: 2541-0482 | ISSN Online: 2541-0490

Open Access at: http://jurnal.untan.ac.id/index.php/tlj

Article Info

Submitted: 11 Desember 2019 | Reviewed: 25 Januari 2020 | Accepted: 2 Maret 2020

\title{
POLITIK HUKUM PENGAMPUNAN PAJAK BERDASARKAN PRINSIP DEMOKRASI PERPAJAKAN SEBAGAI UPAYA PENINGKATAN SUMBER PENERIMAAN NEGARA
}

\author{
Nisa Permata Basti ${ }^{1}$
}

\begin{abstract}
This research is based on the problem of applying the principle of taxation democracy to the politics of tax amnesty as an effort to increase state revenue in the context of tax administration. The first major issues include the application of democratic principles as mandated by the constitution of the provisions of Article 23A of the 1945 Constitution which stipulates that taxes shall be levied under the law. Tax amnesty is one form of short-term tax incentives. Tax Amnesty intended to increase investment to achieve national development. The second major issue concerns the repatriation of assets as a form of taxpayer investment and the implementation of integrated taxpayer data collection as a form of tax administration in order to achieve better national taxation system and future revenues can be further increased. As for the formation of the Tax Amnesty regulation, it must be reviewed based on legislation approach nd the application of democratic principles in the legislative enactment considering one of the tax functions is regulate function.
\end{abstract}

Keyword: legal policy, state revenue, taxation democracy, tax amnesty, taxpayers

\begin{abstract}
Abstrak
Kajian ini menekankan pada pembahasan penerapan prinsip demokrasi perpajakan pada politik hukum pengampunan pajak sebagai upaya peningkatan sumber penerimaan negara dalam konteks administrasi perpajakan. Permasalahan pokok yang pertama antara lain penerapan prinsip demokrasi sebagaimana amanat dari konstitusi ketentuan Pasal 23A UUD 1945 yang mengatur bahwa pajak harus dipungut berdasarkan undang-undang. Pengampunan pajak merupakan salah satu bentuk insentif pajak yang bersifat jangka pendek. Pengampunan Pajak dapat meningkatkan investasi guna mencapai pembangunan nasional. Permasalahan pokok yang kedua berkenaan repatriasi aset sebagai bentuk investasi wajib pajak dan dilakukannya pendataan wajib pajak terintegrasi sebagai bentuk administrasi perpajakan guna mencapai sistem perpajakan nasional yang lebih baik dan penerimaan negara kedepannya dapat lebih meningkat. Adapun dalam pembentukan Undang-Undang Pengampunan Pajak harus dikaji berdasarkan pendekatan IImu Perundang-Undangan serta penerapan prinsip demokrasi dalam pembentukan peraturan perundang-undangan mengingat salah satu fungsi pajak salah adalah fungsi mengatur.
\end{abstract}

\section{Kata Kunci: demokrasi perpajakan, pengampunan pajak, penerimaan negara, politik hukum, wajib pajak}

\footnotetext{
1 Alumni Sarjana IImu Hukum dan Pascasarjana Magister IImu Hukum Fakultas Hukum Universitas Padjadjaran, Bandung, Sekarang Aktif sebagai Advokat/Praktisi Hukum Litigasi dan Non Litigasi serta Dosen Luar Biasa di Podomoro University, Jakarta.
} 


\section{Pendahuluan}

Pemerintah dalam menjalankan tugas dan fungsinya dalam penyelenggaraan pemerintahan berdasarkan kepada kewenangan. Kewenangan tersebut dapat berupa atribusi, delegasi ataupun mandat.

Kewenangan atribusi diberikan langsung melalui ketentuan peraturan perundang-undangan. Sebagaimana yang terdapat dalam ketentuan Konstitusi Indonesia Konstitusi Indonesia sebagai ketentuan peraturan perundang-undangan tertinggi dalam hierarki peraturan perundang-undangan telah mengatur bahwa Indonesia adalah negara hukum yang berkedaulatan rakyat.

Hal ini tercantum dalam ketentuan Pasal 1 ayat (2) Undang-undang Dasar 1945 (selanjutnya disingkat UUD 1945) bahwa Kedaulatan berada di tangan rakyat dan dilaksanakan menurut Undang-undang Dasar. Lembaga legislatif dalam hal ini adalah Dewan Perwakilan Rakyat (selanjutnya disingkat DPR) adalah lembaga yang merepresentasikan kepentingan rakyat.

Pajak adalah salah satu instrumen pembangunan nasional. Melalui instrumen pajak ini pemerintah dapat menjalankan fungsi pelayanan publik (public service) kepada masyarakat. Anggaran biaya belanja pemerintah dibiayai salah satunya melalui pemungutan pajak kepada masyarakat. Pajak harus dipungut melalui ketentuan perundang-undangan karena pajak memiliki sifat membebani masyarakat dan kontraprestasi dalam artian tidak memiliki timbal balik secara langsung kepada masyarakat.

Ketentuan yang mengharuskan pajak dan pungutan lainnya yang memiliki sifat memaksa dan membebani masyarakat baik secara hukum dan secara ekonomi terdapat dalam ketentuan Pasal 23 ayat (2) UUD 1945 sebelum amandemen bahwa "Segala pajak untuk keperluan negara berdasarkan undang-undang" dan diperbaharui dengan ketentuan Pasal 23A UUD 1945 Amandemen Ke-empat yang menentukan bahwa "Pajak dan pungutan lain yang bersifat memaksa untuk keperluan negara diatur dengan undangundang."

Pasal 23 ayat (2) UUD 1945 mempunyai arti yang sangat dalam yaitu menetapkan nasib rakyat. Betapa caranya rakyat sebagai bangsa, akan hidup dan darimana didapatnya belanja hidup harus ditetapkan oleh rakyat itu sendiri dengan perantaraan DPR sebagai wakil mereka. ${ }^{2}$

Rakyat menentukan nasibnya sendiri, karena itu juga cara hidupnya. Oleh karena penetapan belanja mengenai hak rakyat untuk menentukan nasibnya sendiri, maka segala tindakan yang menempatkan beban kepada rakyat, seperti pajak harus ditetapkan dengan undang-undang dengan persetujuan wakil-wakil mereka yang duduk di lembaga legislatif. ${ }^{3}$

\footnotetext{
2 Bohari, 2010, Pengantar Hukum Pajak, Jakarta: Raja Grafindo Persada, hlm. 32.

3 lbid.
} 
Pajak bukan satu-satunya faktor pendorong minat investasi, akan tetapi sistem perpajakan yang berlaku di suatu negara akan menjadi pertimbangan sendiri bagi para investor untuk memilih negara mana yang akan dijadikan tempat investasi. Pengenaan pajak yang relatif kecil atau pembebasan pajak pada suatu negara (tax haven) menjadi menarik bagi investor karena sudah menjadi gejala masyarakat di negara mana pun orang memiliki kecenderungan untuk membayar pajak relatif kecil yang merupakan bentuk pengelakan atau penghindaran pajak (tax avoidance). Tindakan yang demikian jelas akan merugikan penerimaan negara dari sektor pajak (tax loss). ${ }^{4}$

Untuk menggali penerimaan negara dari sektor perpajakan dibutuhkan upayaupaya nyata, serta diimplementasikan dalam bentuk kebijakan pemerintah. Upaya-upaya tersebut dapat berupa intensifikasi maupun ekstensifikasi perpajakan. Intensifikasi pajak dapat berupa peningkatan jumlah Wajib Pajak (WP) maupun peningkatan penerimaan pajak itu sendiri. Upaya ekstensifikasi dapat berupa perluasan objek pajak yang selama ini belum tergarap. Untuk mengejar penerimaan pajak, perlu didukung situasi sosial ekonomi politik yang stabil, sehingga timbul kesadaran masyarakat dan dengan sukarela membayar pajaknya (tax compliance).

\footnotetext{
${ }^{4}$ Zainal Muttaqin. 2013. Tax Amnesty di Indonesia, Bandung: Refika Aditama, hlm. 1-2
}

Demikian juga, salah satu kebijakan yang perlu dipertimbangkan adalah diberikannya tax amnesty atau pengampunan pajak. Kebijakan ini diharapkan dapat meningkatkan subyek pajak maupun obyek pajak. Subyek pajak dapat berupa kembalinya dana-dana yang berada di luar negeri, sedangkan dari sisi obyek pajak berupa penambahan jumlah wajib pajak. ${ }^{5}$

Di berbagai negara yang telah melaksanakan pengampunan pajak, diterima pandangan bahwa pengampunan pajak merupakan bagian dari program kebijakan fiskal negara yang bersangkutan dan bertujuan meningkatkan pendapatan negara dalam jangka pendek. Pandangan yang sama tentang tujuan ini dinyatakan pula oleh Eric Le Borgne. Menurut Eric Le Borgne sebagaimana dikutip oleh Zainal Muttaqin dalam bukunya Tax Amnesty di Indonesia, di samping untuk meningkatkan pendapatan negara dalam jangka pendek, pengampunan pajak juga bertujuan untuk meningkatkan kepatuhan wajib pajak sehingga dapat meningkatkan keadilan horizontal dan meningkatkan pendapatan dalam jangka menengah. ${ }^{6}$

Kebijakan pengampunan pajak (tax amnesty) sebagaimana yang dikehendaki pemerintah melalui adanya pembentukan Undang-undang Nomor 11 tahun 2016

\footnotetext{
${ }^{5}$ Kementerian Keuangan: Ragimun (Peneliti Badan Pelayanan Fiskal Kemenkeu RI), Makalah: "Analisis Implementasi Pengampunan Pajak (Tax Amnesty) di Indonesia."

${ }^{6}$ Zainal Muttaqin, op.cit. hlm. 31.
} 
tentang Pengampunan Pajak dimaksudkan sebagai upaya untuk meningkatkan kesadaran dan kepatuhan wajib pajak dalam menjalankan tertib admininstrasi perpajakan. Kebijakan pengampunan pajak ini merupakan suatu bentuk insentif pajak yang diberikan oleh pemerintah untuk mendorong tingkat kepatuhan wajib pajak.

$$
\text { Kebijakan atas pemberian }
$$
pengampunan pajak kepada wajib pajak dilatarbelakangi oleh faktor adanya potensi pajak sebagai salah satu sumber penerimaan negara pokok dan utama yang tidak diterima oleh pemerintah karena tidak patuhnya wajib pajak dalam menjalani tertib hukum perpajakan, khususnya perihal administrasi perpajakan yaitu basis data Wajib Pajak.

\section{Undang-Undang Pengampunan}

Pajak $^{7}$ memakai dasar Pasal 23A UUD 1945 tentang pajak dan pungutan lain yang bersifat memaksa. Upaya pengampunan pajak baik deklarasi maupun repatriasi melibatkan prosedur dan substansi sehingga memerlukan alas hukum yang tepat pemberlakuannya. Untuk itu, diperlukan struktur logis pertautan antara amnesti pajak, repatriasi, pengampunan, penerimaan dana oleh pemerintah, dan relevansi ekonomis bagi kesejahteraan rakyat. $^{8}$

\footnotetext{
${ }^{7}$ Catatan: RUU Pengampunan Pajak telah disahkan oleh negara sebagai undang-undang resmi dan telah dimuat dalam lembaran negara pada tanggal 1 Juli 2016 menjadi Undang-undang Nomor 11 Tahun 2016 tentang Pengampunan Pajak.

8 lbid
}

Pembentukan UU Pengampunan Pajak hanya terfokus pada manfaat dan tujuan jangka pendek berupa tambahan pemasukan pada penerimaan negara untuk menutup tidak tercapainya penerimaan negara dari sektor pajak (shortfall term). ${ }^{9}$ Sehingga perlu untuk dikaji lebih lanjut mengenai kebijakan jangka panjang mengenai penerimaan negara melalui pajak yang tidak hanya menekankan kebijakan yang sifatnya temporer dengan legitimasi undang-undang sebagai kekuatan memaksanya.

Definisi Pengampunan Pajak menurut Undang-undang Nomor 11 Tahun 2016 Pasal 1 ayat (1) adalah:

"Penghapusan Pajak yang seharusnya terutang, tidak dikenai sanksi administrasi perpajakan dan sanksi pidana di bidang perpajakan, dengan cara mengungkap harta dan membayar uang tebusan sebagaimana diatur dalam undang-undang ini."

Dalam Ketentuan Pasal 2 ayat (2) dijelaskan berkenaan tujuan dari adanya pengampunan pajak, tujuan tersebut antara lain:

"Pasal 2 ayat (2)

a. Mempercepat pertumbuhan dan restrukturisasi ekonomi melalui pengalihan harta, yang antara lain

9 Pasca RUU Pengampunan Pajak, Pemerintah Harus Ajukan RUU Ketentuan Umum Perpajakan, http://www.tribunnews.com/nasional/2016/05/03/pa sca-ruu-pengampunan-pajak-pemerintah-harusajukan-ruu-ketentuan-umum-perpajakan, di akses pada hari Kamis, tanggal 09 Juni 2016, Pukul 22.00 WIB 
akan berdampak terhadap peningkatan likuiditas domestik, perbaikan nilai tukar Rupiah, penurunan suku bunga, peningkatan investasi;

b. Mendorong reformasi perpajakan menuju sistem perpajakan yang lebih berkeadilan serta perluasasn basis data perpajakan yang lebih valid, komprehensif dan terintegrasi; dan

c. Meningkatkan penerimaan pajak, yang antara lain akan digunakan untuk pembiayaan pembangunan."

Melalui UU Pengampunan Pajak, para wajib pajak yang belum melaporkan pajaknya akan mendapat tarif tebusan yang lebih rendah. Tarif tersebut dibagi menjadi tiga kategori, yakni bagi usaha kecil menengah, bagi wajib pajak yang bersedia merepatriasi asetnya di luar negeri, serta deklarasi aset di luar negeri tanpa repatriasi. ${ }^{10}$

Pengampunan Pajak adalah salah satu bentuk insentif pajak. Insentif pajak adalah pemberian fasilitas di bidang pajak kepada investor yang memenuhi kualifikasi tertentu untuk melakukan investasi sesuai dengan peraturan yang memiliki keuntungan dibandingkan fasilitas yang ada pada investasi secara umum. Tidak semua fasilitas pajak yang diterapkan pada seluruh proyek investasi dapat dikategorikan sebagai insentif pajak. ${ }^{11}$

\footnotetext{
10 lbid

11 Zainal Muttaqin, Op.cit, hlm. 13
}

Pengampunan Pajak semestinya diletakan sebagai salah satu bagian dari cetak biru reformasi perpajakan yang utuh dan menyeluruh, bukan kebijakan yang berdiri sendiri. Ini adalah syarat agar tujuan untuk menaikan penerimaan negara dan perluasan basis pajak bisa terwujud. ${ }^{12}$

Penerapan prinsip demokrasi perpajakan dalam politik hukum pembentukan Peraturan perundangundangan khususnya berkenaan Undangundang Pengampunan Pajak mencerminkan amanat dari ketentuan Pasal 23A UUD 1945 amandemen keempat. Repatriasi aset dan pendataan wajib pajak terintegrasi merupakan potential income bagi penerimaan negara dari sektor pajak, kebijakan tax amnesty dimaksudkan untuk mendorong penerimaan negara yang bersumber dari sektor pajak.

Berkenaan dengan adanya pembentukan peraturan perundangundangan berkenaan aspek pengampunan pajak melalui bentuk Undang-undang Pengampunan Pajak penulis dalam hal ini memiliki ketertarikan untuk membahas berkaitan dengan urgensi dan penerapan prinsip demokrasi di bidang perpajakan politik hukum dalam pembentukan UndangUndang Pengampunan Pajak sebagai insentif pajak sebagai sumber penerimaan negara dalam sektor pajak.

Kajian mengenai Pengampunan Pajak ini pernah diteliti sebagai karya ilmiah

12 lbid 
berbentuk Disertasi dengan judul "Pengampunan Pajak Sebagai Insentif dalam Rangka Meningkatkan Investasi di Indonesia" yang ditulis oleh Zainal Muttaqin, Dosen Hukum Pajak dan Hukum Administrasi Negara di Fakultas Hukum Universitas Padjadjaran.

Berdasarkan uraian yang telah dijabarkan di atas, permasalahan pokok yang menjadi pembahasan antara lain: Bagaimana penerapan prinsip demokrasi perpajakan pada politik hukum pengampunan pajak yang meningkatkan penerimaan negara?

\section{Metode}

Metode penelitian dalam penulisan jurnal ini adalah yuridis normatif, yaitu dengan cara meneliti bahan pustaka atau data sekunder yang bersifat hukum. Spesifikasi penelitian dalam penulisan jurnal ini adalah deskriptif analitis yang bersifat menggambarkan apa adanya dan kemudian dianalisis berdasarkan teori-teori dan peraturan perundang-undangan.

\section{Analisis dan Pembahasan}

\section{A. Gagasan Dasar Negara Hukum.}

Prinsip negara hukum merupakan salah satu pilar terpenting tempat demokrasi bersandar. Namun yang dibutuhkan bukan hanya negara hukum dalam arti yang sangat minimal, atau negara hukum dalam artian formal semata, melainkan negara hukum yang benar-benar demokratis yang menjamin hak asasi manusia serta menyediakan mekanisme petanggungjawaban, yang pada gilirannya akan menjamin persamaan seluruh warga negara dan membatasi kemungkinan terjadinya penyalahgunaan kekuasaan negara. ${ }^{13}$

Dalam pembentukan undangundang secara komprehensif memperhatikan 3 (tiga) dimensi, yaitu masa lalu yang terkait dengan sejarah perjuangan bangsa, masa kini yaitu kondisi objektif yang ada sekarang dengan lingkungan strategisnya. ${ }^{14}$

Proses pembentukan undangundang sebagai wujud pembangunan hukum adalah rentetan kejadian yang bermula dari perencanaan, pengusulan, pembahasan dan pengesahan. Dalam sistem pembentukan hukum yang demokratis, proses pembentukan hukum tersebut memiliki tipe buttom up, yakni menghendaki bahwa materiil hukum yang hendak di atur dalam rancangan peraturan perundang-undangan merupakan pencerminan nilai dan kehendak rakyat. ${ }^{15}$

Dalam kepustakaan Indonesia, istilah negara hukum merupakan terjemahan langsung dari rechtstaat. Paham negara hukum berdasarkan keyakinan bahwa kekuasaan negara harus dijalankan atas dasar hukum yang baik dan

\footnotetext{
13 Susi Dwi Harijanti, et.all, 2011. Negara Hukum Yang Berkeadilan (Kumpulan Pemikiran dalam Rangka Purnabakti Prof. Dr. Bagir Manan,S.H.,M.CL). Bandung: PSKN FH UNPAD, hlm. xi

${ }^{14}$ Winda Wijayati. 2013. "Eksistensi Undang-undang Sebagai Produk Hukum Dalam Pemenuhan Keadilan (Analisis Putusan Mahkamah Konstitusi Nomor 50//PUU-X/2012)", Jurnal Konstitusi, 10 (1): 180.

${ }^{15}$ Winda Wijayati, Op.cit, hlm. 180.
} 
adil. Ada dua unsur dalam paham negara hukum: pertama, bahwa hubungan antara yang memerintah dan yang diperintah tidak berdasarkan kekuasaan, melainkan berdasarkan suatu norma obyektif yang juga mengikat pihak yang memerintah dan kedua, bahwa norma obyektif itu, hukum memenuhi syarat bukan hanya secara formal, melainkan dapat dipertahankan berhadapan dengan idea hukum.

Paham negara hukum tidak dapat dipisahkan dari paham kerakyatan, sebab pada akhirnya, hukum yang mengatur dan membatasi kekuasaan negara atau pemerintah diartikan sebagai hukum yang dibuat atas dasar kedaulatan rakyat. Begitu eratnya hubungan antara paham negara hukum dan kerakyatan sehingga ada sebutan negara hukum yang demokratis atau democratische rechtsstaat. Scheltema, memandang kedaulatan rakyat (democratie beginsel) sebagai salah satu dari asas negara hukum, selain rechtszekerheidbeginsel, gelijkheid beginsel, dan het beginsel van de dienendeoverheid. Dalam kaitannya dengan negara hukum, kedaulatan rakyat merupakan unsur material negara hukum, selain masalah kesejahteraan rakyat. ${ }^{16}$

Salah satu asas penting negara hukum adalah asas legalitas. Substansi dari asas legalitas tersebut adalah menghendaki agar setiap tindakan badan/pejabat administrasi berdasarkan

\footnotetext{
${ }^{16} \mathrm{Ni}^{\prime}$ matul Huda. 2016. Hukum Tata Negara (Edisi Revisi). Jakarta: Rajawali Press, hlm. 84-85.
}

undang-undang. Asas legalitas berkaitan erat dengan gagasan demokrasi dan gagasan negara hukum (het democratish ideal en het rechtsstaats ideal). Gagasan demokrasi menuntut agar setiap bentuk undang-undang dan berbagai keputusan mendapatkan persetujuan dari wakil rakyat dan lebih memperhatikan kepentingan rakyat. Gagasan negara hukum menuntut agar penyelenggaraan kenegaraan dan pemerintahan harus didasarkan pada undang-undang dan memberikan jaminan terhadap hak-hak dasar rakyat yang tertuang dalam undang-undang. ${ }^{17}$

\section{B. Prinsip Demokrasi Perpajakan Pada Politik Hukum Pengampunan Pajak.}

Berdasarkan perkembangan studi tentang negara dan pemerintah pada abad modern ini menunjukkan bahwa teori kontrak sosial telah meletakkan landasan yang kuat bagi terbentuknya konsep kekuasaan Negara dan Pemerintah, serta konsep kedaulatan rakyat. Ide kekuasaan di tangan rakyat dan dijalankan oleh pemerintah mulanya dikemukakan oleh Epicurus dan dikembangkan oleh Marsilius yang menjelaskan proses terciptanya pemerintah sebagai pelaksana kedaulatan rakyat bermula ketika terjadi penyerahan tugas (Pactum Subjectiones) dalam bentuk satu konsesi (concession). Marsilius, seperti dalam dikutip oleh Soehino yang dikutip ulang oleh Paimin Napitupulu dalam

\footnotetext{
17 Ridwan HR. 2002. Hukum Administrasi Negara. Yogyakarta: UII Press, hlm. 68-69.
} 
bukunya "Menuju Pemerintahan Perwakilan":

"kekuasaan negara yang tertinggi itu ada pada rakyat, sebab rakyatlah yang berhak membuat peraturan-peraturan hukum atau undang-undang. Hal ini disebabkan karena negara itu merupakan kesatuan dari orangorang yang bebas, merdeka, jadi perimbangan antara kekuasaan rakyat dengan kekuasaan raja adalah rakyat yang berdaulat, raja melaksanakan kedaulatan rakyat."

Padmo Wahyono sebagaimana yang dikutip dari Jurnal Keadilan dalam Laporan Utama: "Reformasi Hukum: Antara Cita dan Fakta", mengatakan bahwa di dalam perkembangan teori kenegaraan, pengertian "rechtstaat" sering dikaitkan dengan pengertian "demokratis", sehingga merupakan sesuatu yang ideal dalam bernegara, ialah pola "Negara Hukum yang Demokratis". Bahwa salah satu syarat negara hukum adalah keterlibatan peran serta rakyat untuk turut serta berpartisipasi salah satu bentuknya dengan dilibatkan dalam memberikan persetujuannya dalam proses pembuatan peraturan perundangundangan $^{18}$

Ajaran kedaulatan rakyat yang berintikan pemerintah dari, oleh dan untuk rakyat selanjutnya melahirkan teori Negara Demokrasi yakni suatu pemerintahan yang dijalankan oleh wakil-wakil rakyat, yang selanjutnya melahirkan konsep

\footnotetext{
${ }^{18}$ Laporan Utama. 2000. "Reformasi Hukum: Antara Cita dan Fakta”, Jurnal Keadilan, 1 (1): 2
}

Representative Goverment dan Democratic Representative. ${ }^{19}$

Sistem hukum Eropa Kontinental mengutamakan penggunaan hukum tertulis yaitu peraturan perundang-undangan sebagai sendi utama dalam sistem hukumnya. Karena itu, negara-negara yang berada dalam sistem hukum kontinental, selalu berusaha untuk menyusun hukumhukumnya dalam bentuk tertulis. Bahkan dalam satu sistematika yang diupayakan selengkap mungkin dalam sebuah kitab undang-undang. Penyusunan semacam ini disebut kodifikasi.

Pemikiran kodifikasi ini dipengaruhi oleh konsepsi negara hukum abad ke 1819. Untuk melindungi masyarakat dari kemungkinan tindak sewenang-wenang dan demi kepastian hukum, kaidah-kaidah hukum harus tertulis dalam bentuk undangundang. Lebih lanjut pemikiran ini menyatakan bahwa, suatu peraturan perundang-undangan itu baik kalau dipenuhi beberapa syarat: Pertama, undang-undang harus bersifat umum (algemeen). Umum baik mengenai waktu, tempat, orang atau obyeknya. Kedua, undang-undang harus lengkap, tersusun dalam suatu kodifikasi. Dalam perkembangan, sifat berlaku umum (algemeenheid) tidak hanya terbatas. ${ }^{20}$

Berbagai keputusan administrasi negara yang bersifat mengatur juga berlaku

\footnotetext{
19 Paimin Napitupulu. 2007. Menuju Pemerintahan Perwakilan. Bandung: Alumni, hlm. 5-7.

20 Bagir Manan. 1992. Dasar-dasar Perundangundangan Indonesia. Jakarta: Ind-Hill-Co, hIm.6
} 
umum. Begitu pula, pengertian berlaku umum dari suatu undang-undang tidak lagi selalu berarti untuk semua orang, berlaku setiap saat, semua tempat dan dalam segala fakta (rechtsfeit). Dalam praktek dapat dijumpai undang-undang yang hanya berlaku untuk kelompok orang tertentu, untuk waktu tertentu atau daerah tertentu. ${ }^{21}$

Besarnya peranan peraturan perundang-undangan terjadi karena beberapa hal:

1. Peraturan perundang-undangan merupakan kaidah hukum yang mudah dikenali (diidentifikasi), mudah diketemukan kembali, dan mudah ditelusuri. Sebagai kaidah hukum tertulis, bentuk, jenis dan tempatnya jelas. Begitu pula pembuatnya.

2. Peraturan perundang-undangan memberikan kepastian hukum yang lebih nyata karena kaidah-kaidahnya mudah diidentifikasi dan mudah diketemukan kembali.

3. Struktur dan sistematika peraturan perundang-undangan lebih jelas sehingga memungkinkan untuk diperiksa kembali dan diuji baik segisegi formal maupun materi muatannya.

4. Pembentukan dan pengembangan peraturan perundang-undangan dapat direncanakan. Faktor ini sangat penting bagi negara-negara yang sedang membangun termasuk membangun sistem hukum baru yang sesuai

21 lbid. dengan kebutuhan dan perkembangan masyarakat. ${ }^{22}$

Tetapi tidak berarti pemanfaatan peraturan perundang-undangan tidak mengandung masalah-masalah, antara lain:

1. Peraturan perundang-undangan tidak fleksibel. Tidak mudah menyesuaikan peraturan perundang-undangan dengan perkembangan masyarakat. Pembentukan peraturan perundangundangan membutuhkan waktu dan tata cara tertentu. Sementara itu masyarakat berubah terus bahkan mungkin sangat cepat. Akibatnya maka terjadi semacam jurang antara peraturan perundangundangan dan masyarakat. Dalam keadaan demikian, masyarakat akan menumbuhkan hukum sendiri sesuai dengan kebutuhan. Bagi masyarakat yang tidak mampu menumbuhkan hukum-hukum sendiri akan "terpaksa" menerima peraturan perundangundangan yang sudah "ketinggalan". Penerapan peraturan perundangundangan yang tidak sesuai itu dapat dirasakan sebagai "ketidakadilan" dan dapat menjadi hambatan perkembangan masyarakat.

2. Peraturan perundang-undangan tidak pernah lengkap untuk memenuhi segala peristiwa hukum atau tuntutan hukum, dan ini menimbulkan apa yang lazim disebut sebagai kekosongan hukum

22 Ibid, hlm. 7-8. 
atau "rechtsvacuum". 23 Barangkali penggunaan istilah yang tepat adalah kekosongan peraturan perundangundangan (wetsvacuum).

Untuk membentuk peraturan perundang-undangan yang baik, perlu diperhatikan berbagai asas (beginselen van behoorlijke regelgeving). Van der Vlies membedakan antara asas-asas formal dan asas-asas material.

Asas-asas formal meliputi:

1. Asas tujuan yang jelas (beginsel van duidelijke doelstelling).

2. Asas organ/lembaga yang tepat (beginsel van het juiste orgaan).

3. Asas perlunya peraturan (het noodzakelijkheidsbeginsel).

4. Asas dapat dilaksanakan (het beginsel van uitvoerbaarheid).

5. Asas konsesus (het beginsel van den consensus).

Asas-asas material meliputi:

1. Asas tentang terminologi dan sistematika yang benar (het beginsel van duidelijke terminologie en duidelijke systematiek).

2. Asas tentang dapat dikenali (het beginsel van kenbaarheid).

3. Asas perlakuan yang sama dalam hukum (het rechtsgelijkheidsbeginsel).

4. Asas kepastian hukum (het rechtszekerheidsbeginsel).

23 Ibid, hlm. 8-9
5. Asas pelaksanaan hukum sesuai keadaan individual (het beginsel van de individuele rechtsbedeling). ${ }^{24}$

Pengertian peraturan perundangundangan secara normatif dalam hukum positif tercantum dalam Undang-undang Nomor 12 Tahun 2011 tentang Pembentukan Peraturan Perundangundangan yaitu:

"Peraturan perundang-undangan adalah peraturan tertulis yang memuat norma hukum yang mengikat secara umum dan dibentuk atau ditetapkan oleh lembaga atau pejabat yang berwenang melalui prosedur yang ditetapkan dalam peraturan perundang-undangan." 25

Secara normatif Asas-asas pembentukan peraturan perundangundangan diatur dalam ketenuan Pasal 5 UU No. 12 Tahun 2011, asas-asas tersebut meliputi:

1. kejelasan tujuan;

2. kelembagaan atau pejabat pembentuk yang tepat;

3. kesesuaian antara jenis, hierarki dan materi muatan;

4. dapat dilaksanakan;

5. kedayagunaan dan kehasilgunaan;

6. kejelasan rumusan; dan

7. keterbukaan

Konsep negara hukum liberal klasik melahirkan konsep Negara Hukum Formal dan Negara Hukum Materiil yang berujung

\footnotetext{
24 Ibid, hlm. 19-20

25 Pasal 1 Undang-Undang Nomor 12 Tahun 2011 tentang Pembentukan Peraturan Perundangundangan
} 
dengan tujuan Negara Kesejahteraan (Welfare State). Dalam konsep negara hukum materiil, prinsip demokrasi adalah cara untuk mewujudkan keadilan prosedural dan keadilan subtansial. Keadilan prosedural itu sendiri yang terbagi menjadi dua bagian keadilan distributif dan keadilan komutatif.

Demokrasi yang berarti kesetaraan dan partisipasi, maka konsep demokrasi perpajakan dapat dimaknai sebagai terbangunnya sistem perpajakan yang menggambarkan adanya kesetaraan antara pemerintah dan masyarakat pembayar pajak, sejak dari proses pembuatan kebijakan perpajakan, pengumpulan pajak dan pemanfaatan uang pajak. Prinsip dari demokrasi yang paling signifikan dan urgen adalah meletakkan kekuasaan di tangan rakyat bukan penguasa. ${ }^{26}$

Keterlibatan dan peran serta masyarakat dalam proses penyusunan kebijakan perpajakan menjadi sangat penting, karena selain dapat mengeliminasi potensi konflik juga dapat meningkatkan kepatuhan sukarela masyarakat secara kolektif. Masyarakat mempunyai hak politik dalam setiap proses politik yang diselenggarakan negara terutama menyangkut kepentingan masyarakat itu sendiri, karena pada dasarnya setiap individu mempunyai hak kebebasan dan mempunyai kedudukan yang setara dalam hak-hak dan kewajiban. ${ }^{27}$

\footnotetext{
26 Ibid, hlm. 94
}

27 Ibid
Demokratisasi dalam pengelolaan pajak adalah pertama, terdapatnya mekanisme perpajakan yang dapat mengatasi konflik kepentingan antara wajib pajak dan pemerintah; kedua, adanya ruang yang memadai bagi partisipasi masyarakat dalam proses pembuatan kebijakan perpajakan; ketiga, terdapatnya perundang-undangan perpajakan yang mencerminkan adanya kesetaraan hukum antara wajib pajak dan pemerintah dan keempat, terdapatnya perubahan pemusatan kekuasaan dari penguasa kepada rakyat yang ditandai oleh adanya akses masyarakat terhadap pengawasan pengelolaan uang pajak. ${ }^{28}$

Peran serta dan keterlibatan rakyat selama ini dalam pembentukan peraturan perundang-undangan masih bersifat "semu" bahkan partisipasi politik rakyat bisa di desain oleh elite-elite politik dengan cara melakukan mobilisasi massa, kapitalisasi klaim yang dilakukan elite politik mengatasnamakan kepentingan rakyat. Akibatnya rakyat tidak memiliki suatu kesadaran politik yang signifikan dalam memainkan peran-peran sosial politiknya. Dalam sistem negara yang seperti apapun, peran serta rakyat tetap memiliki magnet yang besar bagi bangunan masyarakat yang baik. Peran serta rakyat tetap diperlukan untuk mendorong pembangunan, mengawasi pelaksanaan pemerintahan dan mengisi ruang yang

\footnotetext{
28 Ibid, hlm. 94-95
} 
tersedia bagi proses terciptanya suatu tatanan pemerintahan yang berkeadaban. ${ }^{29}$

Pajak dari perspektif ekonomi dipahami sebagai beralihnya sumber daya dari sektor privat kepada sektor publik. Pemahaman ini memberikan gambaran bahwa adanya pajak menyebabkan dua situasi menjadi berubah. Pertama, berkurangnya kemampuan individu dalam menguasai sumber daya untuk kepentingan penguasaan barang dan jasa. Kedua, bertambahnya kemampuan keuangan negara dalam penyediaan barang dan jasa publik yang merupakan kebutuhan masyarakat. $^{30}$

Pemahaman pajak dari perspektif hukum, merupakan suatu perikatan oleh karena adanya undang-undang yang menyebabkan timbulnya kewajiban warga negara untuk menyetorkan sejumlah penghasilan tertentu kepada negara, negara mempunyai kekuatan memaksa dan uang pajak tersebut harus dipergunakan untuk penyelenggaraan pemerintahan. Pendekatan hukum memperlihatkan bahwa pajak yang dipungut harus berdasarkan undangundang sehingga menjamin adanya kepastian hukum, baik bagi fiskus (pengumpul pajak) maupun bagi wajib pajak sebagai pembayar pajak. ${ }^{31}$

Pajak dilihat dari perspektif politik dapat dimaknai sebagai investasi politik seorang warga negara kepada negara.
Investasi dimaksudkan sebagai tabungan rakyat dalam rangka membantu negara dalam membiayai proyek-proyek politiknya, sehingga ada preferensi politik bagi warga negara yang bersangkutan dalam setiap proses politik yang diselenggarakan pemerintah, artinya masyarakat pembayar pajak mempunyai hak suara atau dengan kata lain memiliki semacam "otoritas" untuk mengetahui pengalokasian pajak terutama berkaitan dengan penentuan kebijakan negara seperti mengenai pengumpulan, pengadministrasian dan pemanfaatan pajak. ${ }^{32}$

Dalam pengumpulan pajak, masyarakat pembayar pajak berhak untuk mendapatkan keadilan, baik dalam keadilan vertikal maupun keadilan horizontal. Keadilan dalam hal ini, rakyat harus mengetahui alokasi pajak, rakyat harus paham aturan yang berkaitan dengan kewajiban mereka serta rakyat harus dilibatkan dalam pengambilan keputusan politik yang berkenaan dengan hasil pajak. ${ }^{33}$

Keadilan di dalam Black's law Dictionary (Sixth Edition), dimaknai sebagai "Justice fairly administered according to rules of substantive law, regardless of any procedural errors nor affecting the litigant's substantive rights".

Ini berarti bahwa, apa yang secara formal prosedural benar bisa saja disalahkan secara materiil dan 
substansinya melanggar keadilan. Demikian sebaliknya, apa yang secara formal salah bisa saja dibenarkan jika secara materiil dan substansinya sudah cukup adil dan hakim dapat mentoleransi pelanggaran prosedural asalkan tidak melanggar substansi keadilan. ${ }^{34}$

Keadilan substansial terdapat dalam konsep negara republik Indonesia yang mendasarkan kepada nilai-nilai Pancasila sebagai grundnorm dan ideologi bangsa. Pendekatan melalui Pancasila tidak hanya berdasarkan pendekatan norma-norma hukum, tetapi dari seluruh norma-norma kehidupan bangsa Indonesia. Sebagaimana pendapat Roeslan Saleh yang dikutip dari Buku Ajar Hukum Pajak yang ditulis oleh Dewi Kania Sugiharti dan Zainal Muttaqin bahwa Pancasila didasari oleh pemikiran sebagai susunan tertib kehidupan Indonesia, hukum dan moral dapat dibedakan, tetapi tidak terpisah melainkan satu tunggal dalam grundnorm Pancasila. Pendapat ini diperkuat dengan pendapat Mohammad Hatta, yang menyatakan: ${ }^{35}$

"Pancasila terdiri atas dua lapis fundamen, yaitu: fundamen politik dan fundamen moral (etik agama), dengan meletakkan dasar moral di atas, negara dan pemerintahannya memperoleh dasar yang kokoh, yang memerintahkan berbuat

34 Didik Sukriono. 2013. Hukum Konstitusi dan Konsep Otonomi. Malang: Setara Press, hlm. 102.

${ }^{35}$ Dewi Kania Sugiharti dan Zainal Muttaqin. 2015. Buku Ajar Hukum Pajak. Bandung: Kalam Media dan FH UNPAD, hlm. 30. benar, melaksanakan keadilan, kebaikan dan kejujuran serta persaudaraan ke luar dan ke dalam. Dengan politik pemerintahan yang berpegang kepada moral yang tinggi diciptakan tercapainya suatu keadilan sosial bagi seluruh rakyat Indonesia. Dasar Ketuhanan Yang Maha Esa menjadi dasar yang memimpin cita-cita negara, yang memberi jiwa kepada usaha menyelenggarakan segala yang benar, adil dan baik, sedangkan dasar kemanusiaan yang adil dan beradab adalah kelanjutan dalam perbuatan dan praktek hidup dari dasar yang memimpin tadi. Dasar kemanusiaan yang adil dan beradab harus menyusul, berangkaian dengan dasar yang pertama. Letaknya tidak dapat dipisah dari itu, sebab dia harus dipandang sebagai kelanjutan ke dalam praktek hidup dari citacita dan amal Ketuhanan Yang Maha Esa"

Fungsi negara berdasarkan paham negara kesejahteraan, bukan hanya sekedar memelihara ketertiban namun juga secara aktif mengupayakan kesejahteraan warga negaranya karena negara bukan milik penguasa atau golongan tertentu, tetapi milik semua rakyat. Rakyat sebagai pemegang kedaulatan menentukan nasibnya sendiri, sehingga rakyat jugalah yang menentukan sendiri besarnya pajak yang dibayarkan, karena itu pajak dan pungutan lain yang bersifat memaksa untuk keperluan negara diatur denga undangundang.

Bahwa pemungutan pajak dan pungutan lain itu yang dilakukan oleh negara baik melalui pemerintah pusat 
maupun daerah harus mendapat persetujuan oleh rakyat. Dengan demikian wakil-wakil rakyat memiliki peran yang besar dalam penentuan pajak di dalam segala aspeknya baik jumlah, cara pungutan maupun pemeriksaannya yang secara nyata dituangkan ke dalam undangundang sebagaimana diamanatkan oleh konstitusi dan segala peraturan pelaksananya harus bersumber padanya. ${ }^{36}$

Dalam hukum pajak, aspek keadilan sangatlah penting ditonjolkan, dengan perkataan lain hukum pajak sebagai bagian dari hukum itu sendiri bertujuan menciptakan keadilan, maka hukum pajak semestinya mengandung prinsip-prinsip keadilan karena bagaimanapun pemungutan pajak oleh negara akan mengurangi kekayaan dan pendapatan yang menjadi milik pribadi para pembayar pajak. Hak milik pribadi juga merupakan hal yang dihormati dan dilindungi oleh hukum yang berlaku di negara-negara modern saat ini.

Dasar mewajibkannya dari hukum pajak karena bersumber dari keadilan yang terkandung di dalamnya. Konstruksi berpikir seperti ini mengandung makna bahwa hukum pajak yang tidak mengandung penerapan prinsip-prinsip keadilan maka tidak memiliki kekuatan mewajibkan dan memaksa. ${ }^{37}$

Van den Berge berpendapat sebagaimana yang dikutip oleh Sindian Isa

\footnotetext{
36 Ibid, hlm. 31.

$37 \mathrm{lbid}, \mathrm{hlm} .34$.
}

Djajadiningrat dalam Hukum Pajak dan Keadilan, bahwa pemungutan pajak harus memenuhi pula syarat-syarat keadilan dan sebagai dasar dan batu uji adalah sadar hukum yang nyata ada dalam tiap-tiap masyarakat.

Kranenburg berpendapat bahwa patokan umum adalah asas perbandingan (evenredigheidsbeginsel) yang dirumuskan kira-kira sebagai berikut: setiap anggota masyarakat adalah sama dan sederajat terhadap syarat-syarat untuk suka dan duka, sejauh ia sendiri tidak menciptakan syarat-syarat yang menimbulkan syaratsyarat yang menimbulkan suka dan duka khusus, maka demikian banyaknya suka dan duka harus diberikan padanya, sebagaimana ia menciptakan syarat-syarat itu.

Asas ini dapat dipergunakan sebagai patokan, tapi hendaknya ditambahkan pula bahwa keadilan tercapai jika ada keseimbangan dalam masyarakat, dimana setiap orang mengakui hak dan kewajiban masing-masing, jadi atas dasar hukumnya. Oleh sebab itu, maka Van den Berge berpendapat bahwa sadar hukum (rechtsbewustzijn) itu dapat dipergunakan sebagai batu uji dari keadilan, karena sadar hukum itu dapat diselidiki dalam masyarakat.

\section{Politik Perundang-undangan Pajak.}

Dasar hukum dipungutnya pajak diatur dalam konstitusi UUD NRI 1945 pada Pasal 23A sebagaimana berikut "Pajak dan pungutan lain yang bersifat memaksa untuk 
keperluan negara diatur dengan undangundang". Dalam hal ini negara mempunyai kewenangan untuk memungut pajak berdasarkan kewenangan atribusi yang diberikan Konstitusi UUD NRI 1945.

Sri Soemantri Martosoewignyo dalam Prosedur dan Sistem Perubahan Konstitusi, dengan mengutip JG. Steenbeek, mengemukakan bahwa pada umumnya Undang-Undang Dasar atau Konstitusi berisi tiga hal pokok, yaitu: Pertama, adanya jaminan terhadap hakhak asasi manusia dan warga negaranya; Kedua, ditetapkannya susunan ketatanegaraan suatu negara yang bersifat fundamental; Ketiga, adanya pembagian dan pembatasan tugas ketatanegaraan yang juga bersifat fundamental. ${ }^{38}$

Sehubungan dengan hal tersebut, James Bryce, mengatakan bahwa "Every political constitution has three main objects:

1. To establish and maintain a frame of government under which the work of the state can be efficiently carried on, the aims of such a frame of government being on the one hand to associate the people with government, and on the other hand to preserve public order. To avoid hasty decisions and to maintain a tolerable continuity of policy;

2. To provide due security for the rights of the individual citizen as respects person, property and opinion, so that he

\footnotetext{
38 Ruang Hukum. 2002. "Kritik Terhadap Amandemen Pasal 23 UUD 1945", Bussines News, 14 Februari.
}

shall have nothing to fear from the executive or from the tyranny of an exited majority;

3. To hold the state together, not only to prevent its disruption by the revolt or succession of a part of the nation, but to strengthen the cohesiveness of the country by creating good machinery for connecting the outlying parts with the center, and by appealing to every motive of interest and sentiment, that can leas all sections of the inhabitants to desire to remain united under one governments." 39

Dengan demikian menurut Sri Soemantri, Undang-Undang Dasar sebagai Konstitusi tertulis merupakan sebuah dokumen formal, yang muatannya berisi:

1. Hasil perjuangan politik bangsa di waktu yang lampau;

2. Tingkat-tingkat tertinggi perkembangan ketatanegaraan bangsa;

3. Pandangan tokoh-tokoh bangsa yang hendak diwujudkan, baik untuk waktu sekarang maupun di masa yang akan datang;

4. Suatu keinginan dengan mana perkembangan kehidupan ketatanegaraan bangsa hendak dipimpin. ${ }^{40}$

Dari aspek hukum, khususnya peraturan perundang-undangan, persoalan pengampunan pajak (tax amnesty) mengandung 2 (dua) substansi hukum,

\footnotetext{
39 Ibid

40 Ibid
} 
yaitu legitimasi mengenai tidak memberlakukan peraturan perundangundangan yang berlaku, terutama tentang sanksi administrasi dan sanksi pidana dan bentuk hukum pengaturan pengampunan pajak itu sendiri.

Pemberian insentif khususnya pengampunan pajak pada realisasinya akan menimbulkan berbagai dampak: Pertama, menimbulkan ketidakadilan (inequitable) karena hanya wajib pajak tertentu saja yang akan memeperoleh atau menikmatinya. Kedua, rentan untuk disalahgunakan sehingga perlu ekstra pengawasan dari administrasi pajak. Ketiga, insentif pajak sebagai subsidi pemerintah akan mengakibatkan hilangnya potensi penerimaan negara dari sektor pajak.

Dalam ketentuan Pasal 2 ayat (1) UU Nomor 11 tahun 2016 tentang Pengampunan Pajak (selanjutnya disebut UU Pengampunan Pajak) bahwa pengampunan pajak dilaksanakan berdasarkan asas:

1. Kepastian hukum;

2. Keadilan;

3. Kemanfaatan; dan

4. Kepentingan nasional.

Ketentuan Pasal 2 ayat (2) UU Pengampunan Pajak mencantumkan bahwa pengampunan pajak bertujuan, antara lain untuk:

1. Mempercepat pertumbuhan dan restrukturisasi ekonomi melalui pengalihan harta, yang antara lain akan berdampak terhadap peningkatan likuiditas domestik, perbaikan nilai tukar rupiah, penurunan suku bunga, dan peningkatan investasi;

2. Mendorong reformasi perpajakan menuju sistem perpajakan yang lebih berkeadilan serta perluasan basis data perpajakan yang lebih valid, komprehensif, dan terintegrasi; dan

3. Meningkatkan penerimaan pajak untuk pembiayaan pembangunan.

\section{Peningkatan Sumber Penerimaan Negara dari Sektor Pajak.}

Pembangunan pada hakekatnya adalah upaya sistematis dan terencana oleh masing-masing maupun seluruh komponen bangsa untuk mengubah suatu keadaan menjadi keadaan yang lebih baik dengan memanfaatkan berbagai sumber daya yang tersedia secara optimal, efisien, efektif dan akuntabel, dengan tujuan akhir untuk meningkatkan kualitas hidup manusia dan masyarakat secara berkelanjutan.

Upaya sistematis dan terencana tadi tentu berisi langkah-langkah strategis, taktis dan praktis, karena masing-masing negara memiliki usia kedaulatan, sumber daya andalan dan tantangan yang berbeda. $^{41}$

\section{Pajak sebagai sarana Pembangunan}

Pembangunan nasional dimaksudkan disini adalah pembangunan manusia Indonesia seutuhnya dan pembangunan seluruh masyarakat

\footnotetext{
41 Peraturan Presiden Nomor 02 Tahun 2015 tentang Rencana Pembangunan Jangka Menengah Nasional (RPJMN) 2015-2019.
} 
Indonesia yang bertujuan mewujudkan suatu masyarakat yang adil dan makmur yang merata materiil dan spiritual, berdasarkan Pancasila dalam wadah negara kesatuan Republik Indonesia yang merdeka dan berdaulat.

Pembangunan Nasional yang berlandaskan pada trilogi pembangunan yang meliputi:

a. Pemerataan pembangunan dan hasilhasilnya yang menuju pada terciptanya keadilan sosial bagi seluruh rakyat;

b. Pertumbuhan ekonomi yang cukup tinggi, dan;

c. Stabilitas nasional yang sehat dan dinamis.

Ketiga unsur dari trilogi pembangunan tersebut saling kait mengkait dankarena itu ketiga-tiganya harus dikembangkan secara serasi dan saling memperkuat.

Untuk dapat dicapai sasaransasaran tersebut, maka diperlukan kegiatan-kegiatan pembangunan yang meliputi segala bidang serta persyaratan yang mutlak harus ada, seperti adanya stabilitas nasional, adanya pembiayaan yang memadai dan seterusnya. Di samping itu, segala kebijaksanaan pembangunan di semua bidang dan sektor perlu diserasikan dan diarahkan untuk mencapai sasaransasaran tersebut. ${ }^{42}$

Menurut Rochmat Soemitro menguraikan tentang perumusan

\footnotetext{
42 Rochmat Soemitro. 1982. Pajak dan Pembangunan. Jakarta: Eresco, hlm. 2-3
}

pembangunan yaitu bahwa pembangunan adalah segala usaha baik dari pemerintah maupun dari swasta yang meliputi segala segi kehidupan dan penghidupan penduduk, sehingga dapat memenuhi segala macam dan bentuk kebutuhannya secara layak, bahkan mampu memenuhi peningkatan kebutuhan perkembangan penduduknya sesuai dengan perkembangan ilmu teknologi dan teknik yang semakin maju. Maka oleh sebab itu pembangunan mencakup 4 (empat) hal, yaitu:
a. Rehabilitasi;
b. Extensifikasi;
C. Intensifikasi; dan
d. Pembangunan Baru.

Pembangunan yang dimaksudkan itu harus merupakan suatu pembangunan yang merata dan menyeluruh di seluruh wilayah Tanah Air dan bukan hanya untuk kepentingan suatu golongan atau sebagian dari masyarakat saja, tetapi untuk seluruh rakyat sebagai perbaikan tingkat hidup.

Pembangunan yang bersifat jangka panjang tidak dapat dilaksanakan sekaligus, melainkan harus dilaksanakan secara bertahap. Tujuan setiap tahap pembangunan adalah untuk meningkatkan taraf hidup dan kesejahteraan seluruh rakyat serta meletakkan landasan yang kuat untuk pembangunan tahap berikutnya.

Titik berat dalam pembangunan jangka panjang adalah pembangunan bidang ekonomi dengan sasaran utama, mencapai keseimbangan antara bidang pertanian dan bidang industri, yang berarti 
bahwa sebagian besar dari usaha pembangunan diarahkan kepada pembangunan ekonomi sedangkan pembangunan di bidang-bidang lainnya bersifat menunjang dan melengkapi pembangunan bidang ekonomi, pembangunan di luar bidang ekonomi tersebut dilaksanakan seirama dan serasi dengan kemajuan-kemajuan yang telah dicapai dalam bidang ekonomi.

Demokrasi ekonomi yang menjadi dasar pelaksanaan pembangunan harus memiliki ciri-ciri positif sebagai berikut:

a. Perekonomian harus disusun sebagai usaha bersama berdasarkan asas kekeluargaan dan oleh karena itu di dalam Demokrasi ekonomi tidak dikenal sistem pertentangan kelas.

b. Sumber-sumber kekayaan dan sumber-sumber alam serta keuangan negara harus digunakan dengan pemufakatan perwakilan rakyat, serta pengawasan terhadap kebijaksanaan yang bertalian dengan itu harus ada pada perwakilan rakyat.

c. Cabang-cabang produksi yang penting bagi negara dan yang menguasai hajat hidup orang banyak dikuasasi oleh negara.

d. Warga negara memiliki kebebasan dalam memilih pekerjaan yang dikehendaki serta mempunyai hak akan pekerjaan dan penghidupan yang layak.

e. Hak milik perorangan diakui dan pemanfaatannya tidak boleh bertentangan dengan kepentingan masyarakat (fungsi sosial).

f. Potensi inisiatif dan daya kreasi setiap warga negara dikembangkan sepenuhnya dalam batas-batas yang tidak merugikan kepentingan umum.

g. Fakir miskin dan anak-anak terlantar berhak memperoleh jaminan sosial.

Sebaliknya Demokrasi Ekonomi harus menghindarkan ciri-ciri yang bersifat negatif seperti:

a. Sistem Free Fight Liberalism yang menumbuhkan eksploitasi terhadap manusia dan bangsa lain, yang dalam sejarahnya di Indonesia telah menimbulkan dan menyebabkan kelemahan struktural posisi Indonesia di dalam ekonomi dunia.

b. Sistem Etatisme, di dalam mana negara beserta aparatur ekonomi negara bersifat dominan serta mendesak dan mematikan potensi dan daya kreasi unit-unit ekonomi di luar sektor negara

c. Monopoli yang merugikan masyarakat.

Berdasarkan Undang-undang Nomor 25 Tahun 2004 tentang Sistem Perencanaan Pembangunan Nasional (selanjutnya disebut UU SPPN) dalam konsiderans menimbang bahwa untuk menjamin agar kegiatan pembangunan berjalan efektif, efisien dan bersasaran maka diperlukan perencanaan pembangunan nasional dan bahwa agar dapat disusun perencanaan pembangunan yang dapat menjamin tercapainya tujuan 
negara perlu adanya sistem perencanaan pembangunan nasional.

Pembangunan

Nasional

sebagaimana dimaksud dalam Pasal 1 ayat (2) UU SPPN, pembangunan nasional adalah upaya yang dilaksanakan oleh semua komponen bangsa dalam rangka mencapai tujuan bernegara.

Sedangkan yang dimaksud dengan Sistem Perencanaan Pembangunan Nasional sebagaimana yang diatur dalam Pasal 1 ayat (3) UU SPPN adalah satu kesatuan tata cara perencanaan pembangunan untuk menghasilkan rencana-rencana pembangunan dalam jangka panjang, jangka menengah, dan tahunan yang dilaksanakan oleh unsur penyelenggara negara dan masyarakat di tingkat Pusat dan Daerah.

\section{Pembangunan}

Nasional

diselenggarakan berdasarkan demokrasi dengan prinsip-prinsip kebersamaan, berkeadilan, berkelanjutan, berwawasan lingkungan, serta kemandirian dengan menjaga keseimbangan kemajuan dan kesatuan Nasional (Pasal 2 ayat (1) UU SPPN).

\section{Sistem Perencanaan Pembangunan}

Nasional disusun secara sistematis, terarah, terpadu, menyeluruh dan tanggap terhadap perubahan dan Sistem Perencanaan Pembangunan Nasional ini diselenggarakan berdasarkan Asas umum Penyelenggaraan Negara (Pasal 2 ayat (2) dan Pasal 2 ayat (3) UU SPPN).

Sistem Perencanaan Pembangunan Nasional ini dikemudian diturunkan kembali dalam bentuk Undang-undang yang mengatur berkenaan Rencana Jangka Panjang Nasional. Dalam UU Nomor 17 tahun 2007 tentang Rencana Pembangunan Jangka Panjang Nasional (selanjutnya disebut UU RPJPN), pada konsiderans menimbang bahwa diperlukan perencanaan pembangunan jangka panjang sebagai arah dan prioritas pembangunan secara menyeluruh yang akan dilakukan secara bertahap untuk mewujudkan masyarakat adil dan makmur sebagaimana diamanatkan oleh UUD 1945; dan bahwa Pasal 13 UU SPPN mengamanatkan Rencana Pembangunan Jangka Panjang Nasional yang ditetapkan dengan Undang-undang.

Secara Normatif dalam Pasal 1 ayat (1) UU RPJPN yang dimaksud dengan Rencana Pembangunan Jangka Panjang Nasional (selanjutnya disebut RPJP) adalah dokumen perencanaan pembangunan nasional untuk periode 20 (dua puluh) tahun. Perencanaan ini kemudian diturunkan lagi dengan membuat Rencana Pembangunan Jangka Menengah Nasional (selanjutnya disebut RPJMN). Secara normatif yang dimaksud dengan RPJMN adalah dokumen perencanaan pembangunan nasional untuk periode 5 (lima) tahunan.

\section{Kebijaksanaan Perpajakan}

Kebijaksanaan perpajakan akan digunakan untuk memantapkan kestabilan ekonomi dengan menyempurnakan sifat progresivitas daripada sistem perpajakan. Kebijakan fiskal merupakan faktor utama 
yang menentukan jumlah tabungan pemerintah. Kebijakan fiskal yang dijalankan sedemikian rupa di samping meningkatkan tabungan juga mendorong agar supaya tabungan masyarakat secara langsung atau melalui lembaga-lembaga keuangan dapat dimanfaatkan untuk investasi swasta.

Kebijaksanaan di bidang penerimaan negara akan diabdikan kepada pola pembangunan yang hendak dicapai, karena itu di samping peningkatan penerimaan negara, pemerintah juga memperhatikan faktor-faktor keadilan pembebanan pajak, pemberian bimbingan dan gairah berusaha, serta meingkatkan pelayanan dan memperbaiki prosedur pembayaran pajak.

Kebijaksanaan tersebut antara lain dituangkan dalam berbagai usaha untuk lebih mengintesifkan pungutan-pungutan dan tagihan-tagihan serta tunggakantunggakan pajak. Sistem operasi dari pintu ke pintu atau "door to door operation" dalam rangka menertibkan dan menambah jumlah wajib pajak dilakukan.

Penyempurnaan

pungutan

dilakukan dengan pengenaan pajak dengan tarif yang progresif, pemberian fasilitas dan pembebasan pajak pada sektor-sektor yang penting dan produktif, serta perbaikan prasarana dan peningkatan disiplin aparat perpajakan yang disertai dengan pengenaan sanksi yang tegas bagi para pelanggarnya.

$\begin{array}{ccc}\text { Berkaitan } & \text { dengan } & \text { kebijakan } \\ \text { pengampunan } & \text { pajak, } & \text { kebijakan }\end{array}$

pengampunan pajak ini dilakukan dalam bentuk pelepasan hak negara untuk menagih pajak yang seharusnya terutang.

Pengampunan pajak merupakan salah satu bentuk insentif pajak, pengampunan pajak berbeda dengan insentif pada umumnya dimana keringanan atau fasilitas perpajakan ditawarkan kepada investor baru, maka pengampunan pajak sesuai dngan pengertiannya diberikan kepada investor lama yang sudah menjadi wajib pajak (lama). Oleh karena itu pengampunan pajak, khusus ditujukan bagi investor yang sudah menjadi wajib pajak. $\mathrm{Hal}$ ini mengingat pengampunan pajak lebih berhubungan dengan wajib pajak lama dan tidak berlaku bagi wajib pajak atau investor baru. ${ }^{43}$

Pengampunan pajak yang berisikan pembebasan kewajiban pajak yang sebelumnya tidak dibayar, termasuk pula sanksi administrasi dan sanksi pidana akan membuat wajib pajak tidak ragu atau takut untuk menggunakan dana atau keuntungan yang diperoleh sebelumnya sebagai modal dalam pengembangan investasi. ${ }^{44}$

\section{Sistem Hukum Perpajakan.}

Menurut pendapat Lawrence $\mathrm{M}$. Friedman, Sistem hukum terdiri tiga unsur yaitu substansi hukum, struktur hukum dan budaya hukum. Hubungan ketiga unsur

43 Zainal Muttaqin, Op.Cit, hlm. 82

44 Ibid. 
tersebut saling berkaitan dan melengkapi satu sama lain. ${ }^{45}$

Berkenaan dengan sistem hukum perpajakan, secara substansi hukum pajak terdapat pada pembagian klasifikasi hukum pajak material dan hukum pajak formal. Hukum pajak material diatur lebih lanjut dalam ketentuan UU Perpajakan Nasional yang mengatur secara spesifik berkenaan dengan obyek pajak, sedangkan utuk hukum pajak formal diatur lebih lanjut dalam UU Ketentuan Umum dan Tata Cara Perpajakan (UU KUP).

Secara struktur hukum perpajakan, hal ini berkenaan dengan kewenangan memungut pajak oleh fiskus dan sistem pemungutan terhadap wajib pajak baik yang dilakukan secara self assesment, official assesment dan withholding system.

Secara budaya hukum perpajakan ditekankan kepada aspek kepatuhan secara sukarela oleh wajib pajak dengan kesadarannya atas kewajibannya sebagai warga negara untuk membayar pajak. Kesadaran atas kewajiban untuk membayar pajak ini merupakan konsekuensi logis dari warga negara terhadap negaranya untuk membantu pembiayaan pelayanan publik di masyarakat. Sifat pajak sendiri menurut pendekatan dari segi hukum adalah perikatan yang dibentuk oleh undangundang.

\footnotetext{
${ }^{45}$ Lawrence M. Friedman. 2001. American Law an Introduction, terjemahan Wishnu Basuki. Jakarta: Tatanusa, hlm. 7.
}

Hal ini berkenaan dengan salah satu fungsi pajak yaitu fungsi mengatur (fungsi regulerend). Fungsi mengatur sangat penting peranannya sebagai alat kebijaksanaan pemerintah (fiscal policy) dalam menyelenggarakan politiknya dalam segala bidang. Bahkan dalam negara modern fungsi mengatur justru menjadi tujuan politik dari pajak. Dalam fungsi mengatur inilah terletak suatu lapangan yang luas bagi perpajakan, baik dalam bidang ekonomi maupun dalam bidang sosial budaya. ${ }^{46}$

Fungsi mengatur ini berarti bahwa pajak sebagai alat bagi pemerintah untuk mencapai suatu tujuan tertentu baik dalam bidang ekonomi, moneter, sosial, kultural maupun dalam bidang politik. Dalam fungsi mengatur ini adakalanya pemungutan pajak dengan tarif yang tinggi atau sama sekali dengan tarif nol persen. ${ }^{47}$

Selain fungsi mengatur dalam pajak terdapat fungsi budgeter. Pembangunan hanya dapat terlaksana dengan ditunjang keuangan yang cukup tersedia pada kas negara. Untuk itu pajak merupakan sumber penerimaan terbesar dalam keuangan negara. Pajak memegang peranan dalam keuangan negara lewat tabungan pemerintah untuk disalurkan ke sektor pembangunan dan penyelenggaraan pelayanan publik. ${ }^{48}$

Tabungan pemerintah ini diperoleh dari surplus, penerimaan rutin/biasa setelah

\footnotetext{
${ }^{46}$ Bohari, Op.cit, hlm.133-134

${ }^{47}$ Ibid , hlm. 135

48 lbid, hlm.134
} 
dikurangi dengan pengeluaran rutin/biasa. Penerimaan rutin seperti penerimaan dari sektor pajak, retribusi, bea cukai, hasil perusahaan negara, denda dan sita. ${ }^{49}$

Penerimaan rutin/biasa adalah untuk membiayai pengeluaran rutin/biasa dari pemerintah, seperti gaji pegawai, pembelian alat tulis, ongkos pemeliharaan gedung pemerintah, bunga angsuran pembayaran utang-utang kepada negara lain, perbaikan infrastruktur, tunjangan sosial, dan lain-lain. ${ }^{50}$

Unsur-unsur Pajak adalah:

a. Ada undang-undang pajak yang mendasari;

b. Ada penguasa pemungut pajak;

c. Ada subjek pajak;

d. Ada objek pajak;

e. Ada masyarakat/kepentingan umum; dan

f. Ada Surat Ketetapan Pajak (fakultatif).

Jika salah satu unsur tidak ada, maka tidak mungkin ada pajak. Semua unsur tersebut harus ada sehingga pajak menjadi terealisir. ${ }^{51}$ Sedangkan yang menjadi ciri-ciri pajak adalah:

a. Dapat berupa pajak langsung atau pajak tidak langsung;

b. Dapat dipungut sekaligus atau berulang-ulang;

c. Dapat dipaksakan;

\footnotetext{
49 Ibid

$50 \mathrm{lbid}$

51 Rochmat Soemitro dan Dewi Kania Sugiharti. 2010. Asas dan Dasar Perpajakan Dasar Perpajakan 1. Bandung: Refika Aditama, hlm. 160
}

d. Tanpa ada imbalan yang secara langsung dapat ditunjuk;

e. Untuk memasukkan uang sebanyakbanyaknya ke dalam kas negara;

f. Dapat digunakan sebagai alat pendorong atau alat penghambat;

g. Penggunaan pajak sebagai alat untuk mencapai tujuan yang ada di luar bidang keuangan, termasuk kebijaksanaan, yang lazimnya disebut kebijaksanaan fiskal. ${ }^{52}$

Dalam konteks perpajakan, Norman D. Novak mengemukakan 3 (tiga) unsur pokok sistem perpajakan, yaitu: ${ }^{53}$

a. Tax policy (kebijakan perpajakan)

Kebijakan pajak merupakan bagian dari kebijakan fiskal, maka kebijakan fiskal harus dapat mendorong terciptanya pertumbuhan ekonomi dan tidak menghambat iklim investasi. Oleh karena itu kebijakan perpajakan harus memperhatikan prinsip pemerataan beban pajak, keadilan, kepastian dan kesederhanaan.

b. Tax law (undang-undang perpajakan)

Dalam hubungannya dengan sistem hukum perpajakan, undang-undang perpajakan meruapakan wadah atau tempat dimana kebijakan perpajakan diimplementasikan. Undang-undang perpajakan sebagai produk hukum memberikan legalitas baik pada tataran

\footnotetext{
$52 \mathrm{lbid}$.

53 Zainal Muttaqin. 2011. Disertasi: Pengampunan Pajak Sebagai Insentif Pajak Dalam Rangka Meningkatkan Investasi Di Indonesia. Bandung: Fakultas Hukum Unpad, hlm.101-110.
} 
kebijakan perpajakan maupun tahapan pelaksanaan. Undang-undang perpajakan yang dimaksud dalam sistem perpajakan meliputi seluruh peraturan perundangundangan, baik yang bersifat materiil maupun yang bersifat formil.

c. Tax administration (administrasi perpajakan)

Dalam pengertian administrasi perpajakan, dibatasi pada institusi atau badan yang mempunyai tanggungjawab dan wewenang penagihan pajak beserta pejabatnya serta sistem pemungutan pajak. Adminsitrasi pajak mempunyai peranan penting dan menentukan dalam sistem perpajakan suatu negara karean administrasi perpajakan merupakan pelaksana dari suatau kebijakan yang sudah dituangkan Undang-undang. Keberhasilan sistem perpajakan akan bergantung pada sampai sejauhmana administrasi perpajakan mampu mengimplementasikan tidak hanya sebagai kewajiban semata-mata tetapi juga sebaga hak berperan serta untuk membiayai pembangunan nasional.

\section{Administrasi Perpajakan}

Berdasarkan salah satu konsiderans point menimbang dalam UU Pengampunan Pajak yang salah satunya menimbang "bahwa untuk meningkatkan penerimaan negara dan pertumbuhan perekonomian serta kesadaran dan kepatuhan masyarakat dalam pelaksanaan kewajiban perpajakan, perlu menerbitkan kebijakan pengampunan pajak".
Sebagaimana yang menjadi tujuan dari dibentuknya UU Pengampunan Pajak dalam ketentuan Pasal 2 ayat (2) huruf b yaitu: "mendorong reformasi perpajakan menuju sistem yang lebih berkeadilan serta perluasan basis data perpajakan yang lebih valid, komprehensif dan terintegrasi", tujuan tersebut sangat berkaitan erat dengan persoalan administrasi yakni perihal sistem terintegrasi dan basis data.

Dalam ketentuan UU Pengampunan Pajak terdapat pengelolaan manajemen data dan informasi, Pengertiannya secara normatif sebagaimana dimaksud Pasal 1 angka 13 bahwa: Manajemen data dan Informasi adalah sistem administrasi data dan informasi wajib pajak yang berkaitan dengan pengampunan pajak yang dikelola oleh Menteri.

Administrasi perpajakan merupakan implementasi kebijakan sehingga pemerintah sebagai pengumpul pajak harus dapat melaksanakan administrasi perpajakan yang mudah diakses masyarakat pembayar pajak yang direpresentasikan dengan transparansi dan akuntabilitas. Sedangkan dalam pemanfaatan pajak, masyarakat pembayar pajak sesuai dengan preferensi politiknya lebih berhak mengetahui pemanfaatan pajak yang telah disetorkan kepada negara. Dimensi ini dalam praktek politik pemerintahan di Indonesia belum juga diterapkan, dikarenakan mungkin hingga kini rakyat pembayar pajak belum sepenuhnya memahami penggunaan uang yang telah disetorkan kepada negara. 
Melihat sumber-sumber kekuasaan negara dalam persoalan pajak, maka dengan sendirinya akan terkait pula dengan aturan dasar pengenaan pajak (tax base) di dunia yang dikenal hingga saat ini dan dikelompokkan ke dalam tiga kategori, yaitu: Penghasilan dan Bisnis, Konsumsi dan Kekayaan. ${ }^{54}$

Tarif pajak dalam kategori dasar pengenaan pajak (tatbestand) dapat dijadikan sebagai instrumen proteksi dan instrumen alokatif. Instrumen proteksi ketika tarif pajak dapat berperan sebagai motivator masyarakat dalam meningkatkan kegiatan ekonominya, sedangkan instrumen alokatif karena sifatnya dapat menentukan besaran pajak yang dapat ditarik pemerintah dari masyarakat. Oleh karenanya, setiap terjadi perubahan tarif pajak akan menimbulkan tax incidence, yaitu berubahnya penghasilan dan kekayaan riil masyarakat. ${ }^{55}$

Secara struktural tarif pajak dibagi dalam 4 (empat) jenis yaitu:

a. Tarif proporsional, presentasenya tetap meskipun terjadi perubahan dasar pengenaan pajak;

b. Tarif regresif, tarif pajak menurun ketika dasar pengenaan pajak meningkat;

c. Tarif progresif, tarif pajak akan naik sebanding dengan naiknya dasar pengenaan pajak;

\footnotetext{
54 Edi Slamet dan Syarifuddin Jurdi. 2005. Politik Perpajakan Membangun Demokrasi Negara. Yogyakarta: UII Press, hlm. 92

$55 \mathrm{lbid}, \mathrm{hlm} .93$
}

d. Tarif degresif, kenaikan tarif pajak semakin rendah ketika dasar pengenaan pajaknya semakin meningkat.

\section{Subyek dan Obyek Pengampunan Pajak}

Nomor Pokok Wajib Pajak (selanjutnya disingkat NPWP) sudah diterapkan sebelum adanya tax reform. Dengan adanya pembaharuan pajak, hal ini diperbaharui dan lebih digalakkan serta diinformasikan secara luas kepada masyarakat. Dahulu hanya kepada orang yang dikenakan pajak dan menerima Surat Ketetapan Pajak (selanjutnya disebut SKP) saja yang diberikan nomor pokok. Tetapi sekarang setiap orang dan badan yang memenuhi syarat-syarat untuk dikenakan pajak, wajib mendaftarkan diri dan wajib mendapatkan NPWP. ${ }^{56}$

Yang wajib mempunyai nomor pokok adalah wajib pajak penghasilan. Jadi orang atau badan yang bertempat tinggal/berkedudukan di Indonesia, yang menerima atau memperoleh penghasilan bagi perorangan yang jumlahnya setahun melampaui batas pajak, yaitu yang mempunyai penghasilan yang melebihi Pendapatan Tidak Kena Pajak (selanjutnya disingkat PTKP), wajib mempunyai NPWP walaupun kepadanya belum atau tidak dikenakan pajak atau belum atau tidak diberikan SKP, dan tidak melakukan kewajiban ini dikenakan sanksi. ${ }^{57}$

\footnotetext{
${ }^{56}$ Rochmat Soemitro dan Dewi Kania Sugiharti, Asas dan Dasar Perpajakan..op.cit, hlm. 167.

57 lbid.
} 
Dalam Pasal 39 ayat (1) huruf a UU Nomor 6 Tahun 1983 diberikan ancaman sanksi pidana kepada orang atau badan yang tidak mendaftarkan diri untuk mendapatkan NPWP, sedangkan orang atau badan itu memenuhi syarat yang ditentukan oleh undang-undang untuk dikenakan pajak. Sanksi pidana yang diancamkan ialah pidana penjara paling lama tiga tahun dan atau denda paling tinggi empat kali jumlah pajak yang terutang, yang kurang atau tidak dibayar. Pasal 39 UU Nomor 16 Tahun 2000 meninggikan ancaman pidana tersebut menjadi paling lama 6 (enam) tahun dan denda paling tinggi 4 (empat) kali jumlah pajak terutang yang tidak atau kurang dibayar. Orang atau badan yang hanya merupakan subyek pajak tetapi tidak memenuhi syarat objektif, artinya tidak menerima atau memperoleh penghasilan yang kena pajak, tidak wajib mendaftarkan diri. 58

Wajib pajak yang sudah memiliki NPWP wajib memasukkan Surat Pemberitahuan Pajak Penghasilan setiap tahun secara berkala, hal ini berkenaan dengan kategori sistem pemungutan pajak self assesment system, kecuali wajib pajak yang bekerja pada satu majikan/pemberi kerja dan hanya menerima gaji atau upah yang telah dipotong pajak oleh pemberi kerja dan ini termasuk ke dalam kategori sistem pemungutan pajak withholding

${ }^{58} \mathrm{lbid}, \mathrm{hlm}$ 167-168 system, serta wajib pajak di samping itu tidak mempunyai penghasilan lain. ${ }^{59}$

NPWP ini dimaksudkan untuk kategori pajak langsung. Khususnya pajak penghasilan dan pajak kekayaan. NPWP merupakan suatu tanda pengenal bahwa pemegangnya merupakan orang/badan yang membayar pajak, dan dalam korespondensi dengan Kantor Inspeksi Pajak, NPWP ini wajib disebut. ${ }^{60}$

Berdasarkan ketentuan Pasal 3 ayat (1) UU Pengampunan Pajak setiap wajib pajak berhak mendapatkan pengampunan pajak berdasarkan ketentuan undangundang tersebut Pengampunan pajak dapat diberikan kepada wajib pajak melalui pengungkapan harta yang dimilikinya dalam surat pernyataan.

Berdasarkan Penjelasan Pasal 3 ayat (1) UU Pengampunan Pajak dijelaskan bahwa dalam hal wajib pajak belum mempunyai NPWP, wajib pajak harus mendaftarkan diri terlebih dahulu untuk memperoleh NPWP di kantor Direktorat Jenderal Pajak tempat wajib pajak bertempat tinggal atau berkedudukan.

Dalam ketentuan Pasal 3 ayat (3) Terdapat pengaturan pengecualian dalam kondisi khusus terhadap wajib pajak tertentu, yaitu wajib pajak yang sedang:

a. Dilakukan penyidikan dan berkas penyidikannya telah dinyatakan lengkap oleh kejaksaan;

b. Dalam proses peradilan; atau 
c. Menjalani hukuman pidana, atas tindak pidanadi bidang perpajakan.

$$
\text { Yang menjadi obyek }
$$

pengampunan pajak sebagaimana dimaksud dalam ketentuan ini adalah kewajiban perpajakan yang terdiri atas:

a. Pajak Penghasilan; dan

b. Pajak Pertambahan Nilai atau Pajak Pertambahan Nilai dan pajak Penjualan atas Barang Mewah.

Fasilitas yang akan diberikan kepada wajib pajak yang mengikuti program pemerintah yaitu pengampunan pajak dalam periode yang ditentukan dalam ketentuan UU Pengampunan Pajak ini berupa antara lain:

a. Penghapusan pajak terutang yang belum diterbitkan ketetapan pajak, tidak dikenai sanksi administrasi perpajakan, dan tidak dikenai sanksi pidana di bidang perpajakan, untuk kewajiban perpajakan dalam masa pajak, bagian Tahun Pajak, dan Tahun Pajak, sampai dengan akhir Tahun Pajak Terakhir;

b. Penghapusan sanksi administrasi perpajakan berupa bunga, atau denda, untuk kewajiban perpajakan dalam masa pajak, bagian Tahun Pajak, dan Tahun Pajak sampai dengan akhir Tahun Pajak Terakhir;

c. Tidak dilakukan pemeriksaan pajak, pemeriksaan bukti permulaan, dan penyidikan Tindak Pidana di Bidang Perpajakan, atas kewajiban perpajakan dalam masa pajak, bagian Tahun Pajak, dan Tahun Pajak, sampai dengan akhir tahun Pajak Terakhir; dan

d. Penghentian pemeriksaan pajak, pemeriksaan bukti permulaan, dan penyidikan Tindak Pidana di Bidang Perpajakan, dalam hal ini wajib pajak sedang dilakukan pemeriksaan pajak, pemeriksaan bukti permulaan dan penyidikan Tindak Pidana di Bidang Perpajakan atas kewajiban perpajakan, sampai dengan akhir Tahun Pajak Terakhir, yang sebelumnya telah ditangguhkan. ${ }^{61}$

Berkenaan dengan kebijakan pengampunan pajak, berdasarkan penjelasan dari ketentuan UU Pengampunan Pajak, dikehendaki dengan diaturnya UU Pengampunan Pajak ini menjadi bentuk reformasi perpajakan nasional secara integratif dan komprehensif sebagaimana yang dikehendaki oleh ketentuan UU Pengampunan Pajak, yang dijelaskan dalam kutipan berikut ini:

"Undang-undang ini dapat menjembatani agar harta yang diperoleh dari aktivitas yang tidak dilaporkan dapat diungkapkan secara sukarela sehingga data dan informasi atas harta tersebut masuk ke dalam sistem administrasi perpajakan dan dapat dimanfaatkan untuk pengawasan kepatuhan pemenuhan kewajiban perpajakan di masa yang akan datang."

61 Pasal 11 ayat (5) Undang Undang Nomor 11 Tahun 2016 tentang Pengampunan Pajak 
Dalam penegakan hukumnya diikuti dengan kebijakan lain yang saling berkaitan satu sama lain:

“Kebijakan pengampunan pajak seyogyanya diikuti dengan kebijakan lain seperti penegakan hukum yang lebih tegas dan penyempurnaan UU KUP, Undangundang tentang Pajak Penghasilan, Undang-undang tentang Pajak Pertambahan Nilai Barang dan Jasa dan Pajak Penjualan atas Barang Mewah serta kebijakan strategis lainnya di bidang perpajakan dan perbankan."

\section{Penutup}

Prinsip demokrasi perpajakan harus diterapkan sebagai nilai-nilai yang melandasi dan menjadi pondasi dalam pembentukan undang-undang pajak nasional, karena berdasarkan UUD 1945, kedaulatan berada di tangan rakyat dan dilaksanakan menurut Undang-undang Dasar. Dengan ketentuan ini, bahwa pemegang kekuasaan tertinggi ada di tangan rakyat dan harus dilaksanakan menurut Undang-undang Dasar. Hal ini merupakan konsekuensi logis dari konsepsi bentuk Negara Hukum Demokratis yang mendasarkan kepada Undang-undang. UUD 1945 juga mengatur bahwa Pajak dan pungutan lain yang bersifat memaksa untuk keperluan negara diatur dengan undang-undang.

Salah satu manfaat Pungutan Pajak adalah sebagai alat pendorong investasi. Dalam upaya peningkatan sumber penerimaan negara, Pemerintah menghendaki adanya basis data perpajakan melalui manajemen data dan informasi. Maka hal ini dapat diwujudkan dengan cara pengelolaan NPWP wajib pajak sebagai basis data perpajakan yang terintegrasi. Melalui pendataan wajib pajak dengan pendaftaran NPWP sebagai basis data potensi penerimaan negara dari sektor pajak diharapkan semakin meningkat.

\section{Bibliografi}

\section{Buku}

Bagir Manan. 1992. Dasar-dasar Perundang-undangan Indonesia. Jakarta: Ind-Hill-Co.

Bohari. 2010. Pengantar Hukum Pajak. Jakarta: Raja Grafindo Persada.

Dewi Kania Sugiharti dan Zainal Muttaqin, 2015. Buku Ajar Hukum Pajak. Bandung: Kalam Media dan FH UNPAD.

Didik Sukriono. 2013. Hukum Konstitusi dan Konsep Otonomi. Malang: Setara Press.

Edi Slamet dan Syarifuddin Jurdi. 2005.

Politik Perpajakan Membangun Demokrasi Negara. Yogyakarta: UII Press.

Friedman, Lawrence M. 2001. American Law an Introduction, terjemahan Wishnu Basuki. Jakarta: Tatanusa.

Ni'matul Huda. 2016. Hukum Tata Negara (Edisi Revisi). Jakarta: Rajawali Press.

Paimin Napitupulu. 2007. Menuju

Pemerintahan Perwakilan.

Bandung: Alumni.

Ridwan HR. 2002. Hukum Administrasi Negara. Yogyakarta: UII Press. 
Rochmat Soemitro. 1982. Pajak dan Pembangunan. Jakarta: Eresco.

Rochmat Soemitro dan Dewi Kania Sugiharti. 2010. Asas dan Dasar Perpajakan 1, Bandung: Refika Aditama.

Susi Dwi Harijanti, et.all. 2011. Negara Hukum Yang Berkeadilan (Kumpulan Pemikiran dalam Rangka Purnabakti Prof. Dr. Bagir Manan,S.H.,M.CL). Bandung, PSKN FH UNPAD.

Zainal Muttaqin. 2011. "Disertasi: Pengampunan Pajak Sebagai Insentif Pajak Dalam Rangka Meningkatkan Investasi Di Indonesia", Bandung: Fakultas Hukum Unpad.

Zainal Muttaqin. 2013. Tax Amnesty di Indonesia. Bandung: Refika Aditama.

\section{Jurnal}

Laporan Utama. 2000. "Reformasi Hukum:

Antara Cita dan Fakta". Jurnal Keadilan, Vol. 1, No. 1.

Winda Wijayati. 2013. "Eksistensi Undangundang Sebagai Produk Hukum Dalam Pemenuhan Keadilan (Analisis Putusan Mahkamah Konstitusi Nomor 50//PUU-X/2012)". Jurnal Konstitusi, Vol. 10, No. 1.

\section{Peraturan Perundang-Undangan}

Undang Undang Dasar Negara Republik Indonesia 1945.

Undang-Undang Nomor 25 Tahun 2004 tentang Sistem Perencanaan Pembangunan Nasional.
Undang-Undang Nomor 17 Tahun 2007 tentang Rencana Pembangunan Jangka Panjang Nasional Tahun 2005-2025.

Undang-Undang Nomor 16 Tahun 2009 tentang Ketentuan Umum dan Tata Cara Perpajakan.

Undang-Undang Nomor 12 Tahun 2011 tentang Pembentukan Peraturan Perundang-undangan.

Undang-Undang Nomor 11 Tahun 2016 tentang Pengampunan Pajak.

Peraturan Presiden Nomor 02 tahun 2015 tentang Rencana Pembangunan Jangka Menengah Nasional Tahun 2015-2019.

Peraturan Presiden Nomor 03 Tahun 2015 tentang Perubahan atas Peraturan Presiden Nomor 43 Tahun 2014 tentang Rencana Kerja Pemerintah tahun 2015.

Peraturan Menteri Keuangan Nomor 118/PMK.03/2016 tentang Pelaksanaan Undang-undang Nomor 11 Tahun 2016 tentang Pengampunan Pajak.

\section{Media Massa}

Ruang Hukum. 2002. "Kritik Terhadap Amandemen Pasal 23 UUD 1945". Bussines News, 14 Februari. 